\title{
Effects of streptozotocin-induced diabetes and diet on nitrogen loss from organs and on the capacity of urea synthesis in rats
}

\author{
T.P. Almdal and H. Vilstrup \\ Divisions of Hepatology and Experimental Pathology, Rigshospitalet, Copenhagen, Denmark
}

\begin{abstract}
Summary. Rats with experimental streptozotocin-induced diabetes $(75 \mathrm{mg} / \mathrm{kg})$ were divided into two groups. One group was free fed $(n=8)$, the other group $(n=7)$ pair fed to a group of control animals $(n=8)$. The nitrogen and energy balances of the control rats were positive. In the free-fed diabetic rats the nitrogen balance was neutral and the energy balance higher than in controls. In the pair-fed diabetic rats the nitrogen balance was negative and the energy balance reduced. After 4 weeks the capacity of urea-nitrogen synthesis was: $8.1 \pm 0.6 \mu \mathrm{mol} /(\mathrm{min} 100 \mathrm{~g}$ body weight) (mean \pm SEM) in controls and $22.2 \pm 2.2 \mu \mathrm{mol} /(\min 100 \mathrm{~g}$ body weight) in both groups of diabetic rats. Initially, the whole body nitrogen content was $453 \pm 9 \mathrm{mmol}$. Four weeks later it was $536 \pm 19 \mathrm{mmol}$ in controls, $410 \pm 21 \mathrm{mmol}$ in the free-fed dia-
\end{abstract}

betic rats, and $315 \pm 6 \mathrm{mmol}$ in the pair-fed diabetic rats. The largest changes occurred in the muscles, initially containing $278 \pm 6 \mathrm{mmol}$, 4 weeks later $328 \pm 8 \mathrm{mmol}$, compared to $234 \pm 19$ in the free-fed diabetic rats and $166 \pm 18 \mathrm{mmol}$ in the pair-fed diabetic rats. In conclusion uncontrolled diabetes is characterised by loss of nitrogen from muscles and most other organs. The losses from some organs are preventable by increased food intake. Irrespective of food intake the hepatic dynamics of amino nitrogen conversion is changed in a way that favours protein catabolism.

Key words: Experimental diabetes, urea synthesis, nitrogen metabolism, nitrogen balance, protein metabolism.
Uncontrolled or poorly controlled diabetes patients loose protein [1]. It is supposed that hypoinsulinaemia leads to increased release of amino acids from protein stores, predominantly muscles. There may be losses from other organs, i.e. intestines, liver, kidneys, etc., but it has not been investigated quantitatively. The importance of dietary changes is unknown.

The amino acids released from the organs are taken up by the liver and used for protein synthesis or metabolised to glucose and urea. The glucose production and urea excretion are increased in diabetes [2]. This is thought to be secondary to increased supply of substrates to the liver. It has been shown, however, that the capacity of urea synthesis is increased in diabetic rats [3], suggesting that changes in the liver may play a primary role in the abnormal protein loss of diabetes.

The purpose of the present study was to measure the protein contents of various organs and the capacity of urea synthesis in rats with uncontrolled diabetes free fed or pair fed to controls.

\section{Materials and methods}

\section{Animals and diets}

After an overnight fast diabetes was induced in female Wistar rats weighing $220 \mathrm{~g}$ by intravenous injection of streptozotocin (Zanosar,
Upjohn Co, Kalamazoo, Mich, USA), $75 \mathrm{mg} / \mathrm{kg}$ body weight (BW) dissolved in isotonic saline at $\mathrm{pH} 4.5$. The control rats received the vehicle.

The rats were kept single in metabolic cages for 5 weeks in a thermostated room with a 12-h light-dark cycle. They had free access to water and were fed with pulverized diet (Altromin Werke, Lage, FRG) from the same batch.

On the last 2 days of every week the following were determined:

Nitrogen $(\mathrm{N})$ balance $(\mathrm{mmol} / 24 \mathrm{~h})=$ food amount $(\mathrm{g}) \times$ food $\mathrm{N}$ concentration $(\mathrm{mmol} / \mathrm{g})-($ urine $\mathrm{N}+$ feces $\mathrm{N}$ )

Energy balance $(\mathrm{KJ} / 24 \mathrm{~h})=$ food $(\mathrm{g}) \times$ caloric value $(13 \mathrm{KJ} /$ g) - glucose lost in urine $(\mathrm{mmol}) \times$ caloric value $(2.9 \mathrm{KJ} / \mathrm{g})$

\section{Protocols}

On day 9 the animals were randomly allocated to either: I Controls: animals given saline and fed free $(n=8)$, or II Diabetes free fed: animals given streptozotocin and free fed $(n=8)$, or

III Diabetes pair fed: animals given streptozotocin and pair fed, i.e. every day only allowed the same amount of food as the average of that taken by the controls $(n=7)$.

\section{Nitrogen contents in organs}

Following determination of the capacity of urea-N synthesis (CUNS), the animals were dissected into: kidneys, liver, heart, intestines, skin, and carcass (comprising muscles, bones and nervous system). Intestines and carcass were homogenized and samples were frozen. Samples of the skin were hydrolysed in boiling $50 \% \mathrm{KOH}$ and samples were frozen. The kidneys, livers, and hearts were frozen in toto. 
Table 1. The total nitrogen (N) content and nitrogen contents of carcass, heart, intestines, liver, kidneys, and skin from rats at start of experiment (start), and after 4 weeks in metabolic cages in control rats (control), free fed diabetic rats (diabetes free fed) and diabetic rats pair fed to the control rats for 4 weeks (diabetes pair fed)

\begin{tabular}{|c|c|c|c|c|}
\hline & $\begin{array}{l}\text { Start } \\
(n=9)\end{array}$ & $\begin{array}{l}\text { Control } \\
(n=8)\end{array}$ & $\begin{array}{l}\text { Diabetes free } \\
\text { fed }(n=7)\end{array}$ & $\begin{array}{l}\text { Diabetes pair } \\
\text { fed }(n=7)\end{array}$ \\
\hline Total N (mmol) & $453 \pm 9$ & $536 \pm 19^{\mathrm{a}}$ & $410 \pm 21$ & $315 \pm 6^{\mathrm{cd}}$ \\
\hline Heart N (mmol) & $1.30 \pm 0.03$ & $1.31 \pm 0.04$ & $1.14 \pm 0.05^{\mathrm{e}}$ & $0.99 \pm 0.04^{\mathrm{c} d \mathrm{~d}}$ \\
\hline Intestine $\mathrm{N}(\mathrm{mmol})$ & $26.1 \pm 1.0$ & $28.1 \pm 1.1$ & $39.7 \pm 2.6^{\mathrm{b}}$ & $29.6 \pm 3.1$ \\
\hline Liver N (mmol) & $14.6 \pm 0.6$ & $16.7 \pm 0.6^{\mathrm{a}}$ & $17.6 \pm 0.9^{b}$ & $15.0 \pm 0.7$ \\
\hline Kidney N (mmol) & $2.65 \pm 0.07$ & $3.55 \pm 0.18^{\mathrm{a}}$ & $3.45 \pm 0.19^{b}$ & $2.96 \pm 0.16$ \\
\hline
\end{tabular}

Results are mean \pm SEM, ${ }^{\text {a }}$ Control higher than start: $p<0.01 ;{ }^{b}$ Diabetes free fed higher than start: $p<0.01$; ${ }^{\mathrm{c}}$ Diabetes pair feed lower than start: $p<0.01$; ${ }^{\mathrm{d}}$ Diabetes pair fed lower than Diabetes free fed: $p<0.01 ;{ }^{\mathrm{e}}$ Diabetes free fed lower than start: $p<0.01$

Table 2. Insulin and glucagon concentrations before starting and at the end of alanine infusion in control rats, free fed diabetic rats (diabetes free fed) and diabetic rats pair fed to the control rats for 4 weeks (diabetes pair fed)

\begin{tabular}{lcccc}
\hline & $\begin{array}{l}\text { Control } \\
\text { rats }\end{array}$ & $\begin{array}{l}\text { Diabetes free } \\
\text { fed }\end{array}$ & \multicolumn{2}{c}{$\begin{array}{l}\text { Diabetes pair } \\
\text { fed }\end{array}$} \\
\hline $\begin{array}{l}\text { Insulin, fasting } \\
(\mathrm{mU} / \mathrm{ml})\end{array}$ & $16 \pm 2$ & $9 \pm 2$ & $2 \pm 1$ \\
$\begin{array}{l}\text { Insulin, alanine } \\
\text { stimulated (mU/ml) }\end{array}$ & $46 \pm 8$ & $7 \pm 2$ & $6 \pm 2$ \\
$\begin{array}{l}\text { Glucagon, fasting } \\
\text { (pg/ml) }\end{array}$ & $67 \pm 20$ & $230 \pm 51$ & $178 \pm 41$ \\
$\begin{array}{l}\text { Glucagon, alanine } \\
\text { stimulated (pg/ml) }\end{array}$ & $450 \pm 9$ & $698 \pm 115$ & $978 \pm 200$ \\
\hline
\end{tabular}

Results are mean \pm SEM

Table 3. The fasting alpha amino-N (A-A-N) and the capacity of urea- $\mathrm{N}$ synthesis (CUNS) in control animals, free fed diabetic rats (diabetes free fed) and diabetic rats pair fed compared to the control rats for 4 weeks (diabetes pair fed)

\begin{tabular}{llcc}
\hline & $\begin{array}{l}\text { Control } \\
(n=5)\end{array}$ & $\begin{array}{l}\text { Diabetes free } \\
\text { fed }(n=5)\end{array}$ & $\begin{array}{l}\text { Diabetes pair } \\
\text { fed }(n=6)\end{array}$ \\
\hline $\begin{array}{l}\text { Fasting A-A-N } \\
(\mathrm{mmol} / 1)\end{array}$ & $4.9 \pm 0.3$ & $4.7 \pm 0.2$ & $4.3 \pm 0.3$ \\
$\begin{array}{l}\mathrm{CUNS} \\
(\mu \mathrm{mol} / \mathrm{min} 100 \mathrm{~g}\end{array}$ & $8.7 \pm 0.6$ & $22.2 \pm 2.2$ & $22.0 \pm 1.5$ \\
$\mathrm{BW})$ & & & \\
\hline
\end{tabular}

Results \pm SEM

\section{Analyses}

Blood urea concentration: the urease-Berthelot method [4]. Blood total alpha-amino-N: the dinitrofluorobenzene method [5]. Glucose concentration in blood and urine: the glucose oxidase technique (rapid glucose analyser, Yellow Springs Instruments, Yellow Springs, Ohio, USA). Plasma insulin and glucagon concentrations: radio-immunoassay [6, 7], glucagon after ethanol extraction.

Nitrogen contents in excreta and in organs were measured by micro Kjeldahl technique (Keltec Systems, Tecator AB, Hoganaes, Sweden). Urine was analysed once, feces in duplicate, samples of tissues in triplicate. The total body nitrogen was calculated as the sum of all organs.

\section{Validation of the method for determination of nitrogen contents of organs}

The sampling and analysis coefficient of variation of $\mathrm{N}$-contents of the various samples were as follows: urine: $0.70 \%$, feces: $3.4 \%$, car- cass homogenate: $4.5 \%$, intestine homogenate: $0.8 \%$, liver $4.5 \%$. The nitrogen contents in kidneys and heart were too small to allow variation studies. The recovery did not differ from $100 \%$. For further validation rats were processed as follows:

1: 4 animals dissected, organs processed as above.

2: 4 animals dissected. Heart and kidneys frozen in toto. Skin, carcass, intestines and liver hydrolysed in boiling $50 \% \mathrm{KOH}$.

3: 4 whole animals hydrolysed in boiling $50 \% \mathrm{KOH}$.

Results of groups 1 and 2 were identical demonstrating that the homogenizing technique is precise. The calculated total nitrogen contents of groups 1 and 2 were $447 \pm 18 \mathrm{mmol}$ and $457 \pm 13 \mathrm{mmol}$ (mean $\pm S E M$ ), respectively, and in group 3 the total nitrogen content was measured to be $488 \pm 15$. This demonstrates the accuracy of the method. The results from these animals are given as initial values in the "Results" section.

\section{The capacity of urea-nitrogen synthesis (CUNS)}

On day 36 , after an overnight fast, the rats were anaesthetised by thiopental, $50 \mathrm{mg} / \mathrm{kg}$ body weight i. p., thracheotomised, nephrectomised and had catheters placed in a jugular vein for infusion and in a common carotic artery for blood sampling.

Alanine was administered as a priming dose of $0.4-0.7 \mathrm{ml}$ of a $1009 \mathrm{mmol} / \mathrm{l}$ solution in sterile water followed by a constant infusion of $2.0-3.5 \mathrm{ml} / \mathrm{h}$ of a $224 \mathrm{mmol} / 1$ solution by means of a roller pump (Perfursor Secura, Braun, Melsungen, FRG), adjusted so as to obtain steady state within the amino acid concentration interval $7.6-11.3 \mathrm{mmol} / 1$, where the urea synthesis is at maximum [3, 8], i.e. saturated and thus substrate concentration independent.

After $20 \mathrm{~min}$, blood was sampled $(100 \mu \mathrm{l})$ every $10 \mathrm{~min}$. CUNS $(\mu \mathrm{mol} /(\min 100 \mathrm{~g} \mathrm{BW}))$ was calculated as:

CUNS $=\mathrm{dcu} / \mathrm{dt} \times 0.63 \times \mathrm{BW} \times(1 /(1-0.20))$

Here $\mathrm{dcu} / \mathrm{dt}$ is the slope of the linear regression analysis of urea concentration on time, 0.63 is the volume of distribution of urea (identical in normal and in diabetic rats [3,8]) and $1-0.20$ is the fractional intestinal hydrolysis of newly synthesized urea (identical in normal and in diabetic rats $[3,8]$ ).

\section{Statistical analysis}

Differences between groups were evaluated by Student's t-tests. $p$ values smaller than 0.05 were considered statistically significant. When more than two groups were compared the significance levels were adjusted to compensate for the risk of mass significance [9]: $p^{1}=1-\sqrt[n-1]{(1-p)}$. Differences among variables were tested by one way analyses of variance.

\section{Results}

The control animals gained about $7 \mathrm{~g} /$ week. The diabetic animals lost $30-40 \mathrm{~g}$ within the first week. There- 
after, the free fed diabetic animals maintained a body weight of about $200 \mathrm{~g}$, whereas the pair fed diabetic animals lost about $10 \mathrm{~g} /$ week. The control rats had a constant food intake of about $18 \mathrm{~g} / 24 \mathrm{~h}$. The free fed diabetic animals doubled their food intake within 2 weeks.

After 4 weeks the total nitrogen contents of the control rats increased by $20 \%$ (Table 1), remained unchanged in the free fed diabetic rats, and fell by $30 \%$ in the pair fed diabetic animals. The carcass nitrogen contents of the control rats also increased by $20 \%$, remained constant in the free fed diabetic rats, and decreased by $40 \%$ in the pair fed diabetic animals. The nitrogen contents of the heart did not change in the control rats, decreased by $12 \%$ in the free fed diabetic rats, and by $25 \%$ in the pair fed diabetic rats.

The nitrogen contents of the intestines remained unchanged in the control and pair fed diabetic animals, whereas it increased by $40 \%$ in the free fed diabetic animals. The nitrogen contents of the liver increased by $15 \%$ in the controls, by $20 \%$ in the free fed diabetic animals, and remained constant in the pair fed diabetic animals. The nitrogen contents of the kidneys increased by $30 \%$ in the control rats and in the free fed diabetic rats, and remained constant in the pair fed diabetic animals.

The nitrogen contents of the skin increased by $15 \%$ in the control rats, decreased by $13 \%$ in the free fed diabetic rats and by $17 \%$ in the pair fed diabetic rats.

Both groups of diabetic animals had reduced $(p<$ 0.01 ) fasting as well as alanine stimulated insulin concentrations (Table 2). The diabetic animals had 3- to 4-fold higher $(p<0.05)$ fasting glucagon levels.

The fasting blood alpha-amino- $\mathrm{N}$ concentrations were not different among the three groups of animals (Table 3).

The fasting blood glucose was $5.1 \pm 0.4 \mathrm{mmol} / 1$ (mean $\pm \mathrm{SEM}$ ) in control rats. It was increased in free fed diabetic rats: $16.3 \pm 1.8 \mathrm{mmol} / 1$, and in pair fed diabetic rats: $18.0 \pm 2.5 \mathrm{mmol} / 1(p<0.01)$.

The capacity of urea-nitrogen synthesis increased by 2.5 -fold in both groups of diabetic animals $(p<$ 0.01 , Table 3 ).

In the control animals the nitrogen-loss was constant. Fifty percent was excreted as urea, $10 \%$ as nonurea nitrogen of urine, and $40 \%$ as feces nitrogen (Fig.1).

The total nitrogen loss of the free fed diabetic animals increased three-fold. The relative contribution from urea, non urea nitrogen, and feces did not change. In the control fed diabetic rats the total nitrogen loss increased by $50 \%$ due to increased urinary losses.

The nitrogen balance of the control animals was constant (Fig. 2). The nitrogen balance of the free fed diabetic animals was neutral. The control fed animals had a constantly negative nitrogen balance.

The free fed diabetic animals gradually increased

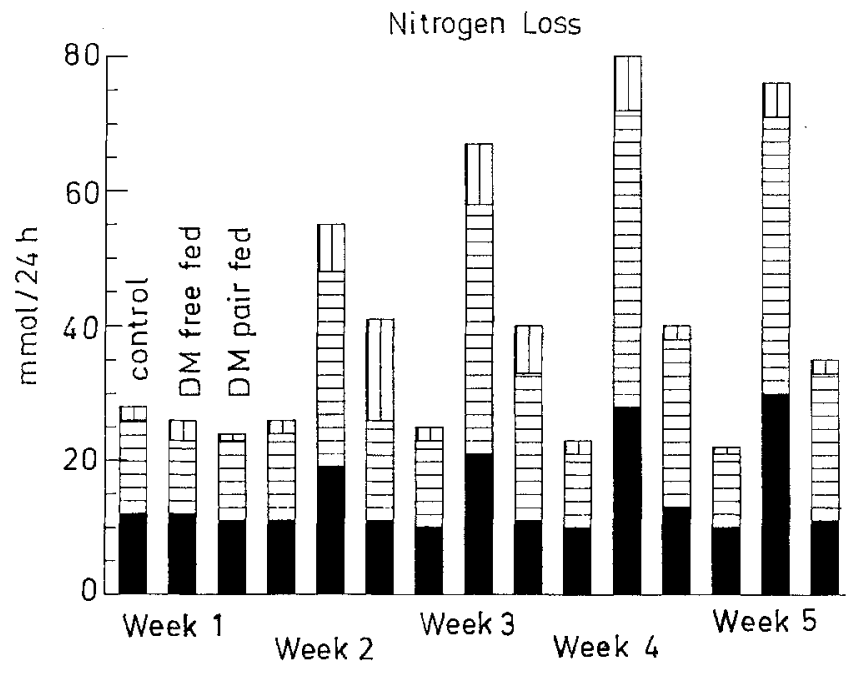

Fig. 1. The amount of nitrogen lost in feces $(\square)$, as urea $(\theta)$, and as other nitrogen-containing substances of urine (IID) in control rats, diabetic rats free fed (DM free fed) and diabetic rats pair fed to the control rats (DM pair fed). Results are given as mean with $95 \%$ confidence limits

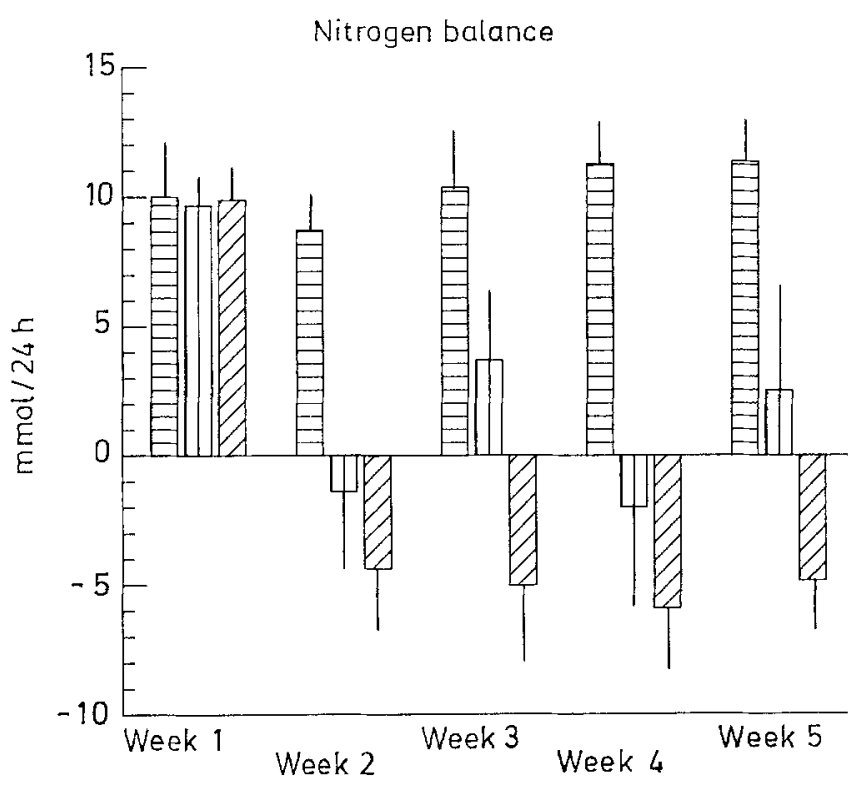

Fig. 2. The calculated nitrogen balance of control rats $(\Theta)$, diabetic rats free fed (ID) and diabetic rats pair fed (B) compared to the control rats. Results are given as mean with $95 \%$ confidence limits

their glucose output over 2 weeks to $75 \mathrm{mmol} / 24 \mathrm{~h}$. The control fed diabetic animals had a constant glucose output of about half of that of the free fed diabetic animals.

The control animals had a constant energy balance throughout the study (Fig.3). Initially, the free fed diabetic animals had an energy balance not different from that of the controls, whereafter they developed a positive energy balance, $20 \%$ higher than that of the controls. The energy balance of the control fed animals was $50-60 \%$ of the control values throughout the study. 


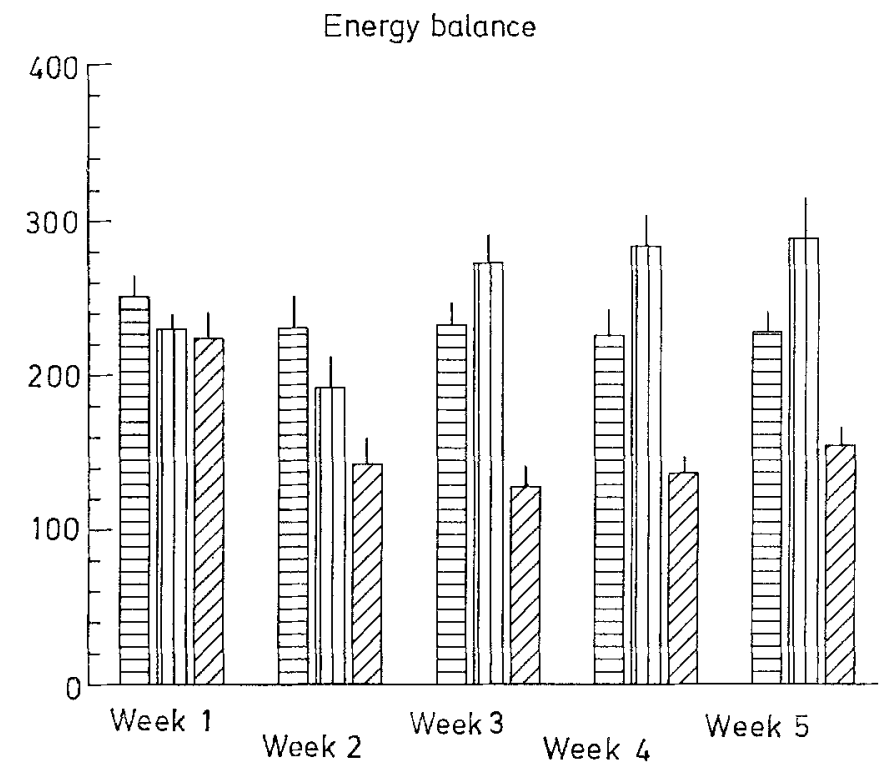

Fig.3. The calculated energy balance of control rats $(\boxminus)$, diabetic rats free fed (III) and diabetic rats pair fed (Q) to the control rats (DM pair fed). Results are given as mean with $95 \%$ confidence limits

\section{Discussion}

This study confirms experimentally that uncontrolled diabetes leads to a negative nitrogen balance and loss of proteins, mostly from muscles. Protein was also lost from most other organ systems, and the hepatic dynamics of amino nitrogen conversion was changed. The diet restriction had different effects on the nitrogen wasting of different organs.

Protein synthesis and breakdown takes place simultaneously [10], and any imbalance between them leads to changes in the protein mass. The results of the study reflect the net result of these two processes in the diabetic rat. Other studies have shown a loss of protein from skeletal [11-13] and heart muscles [12, 14], which is confirmed by the present study. It is a new observation that the degree of loss from muscles depends on the food intake.

The few observations on gastrointestinal organs suggest that synthesis is normal in the intestines and reduced in the liver $[15,16]$. Observations on breakdown are missing. This study demonstrates that the protein contents of both liver and intestines were affected differently from that of the muscles mass: the protein content of the intestines was normal on a normal food intake and increased on an increased food intake. Normal liver protein content was only achieved on an increased food intake.

Short term experimental diabetes is associated with increased kidney volume and weight [17]. Our study demonstrates that this is not due to increased protein contents, as the free fed diabetic animals had normal protein contents and the control fed animals did not have increased protein contents.

There is no earlier study on the protein contents of the skin of diabetic animals. This study shows that the skin protein content, which is taken to reflect the connective tissue in general, is decreased in diabetic rats, irrespective of feeding regimen.

The diabetic animals were hypoinsulinaemic. Lack of insulin leads to increased release of amino acids from muscles in the perfused rat hemicorpus [18] and the rat diaphragm [19] as a consequence of decreased protein synthesis and an increased protein degradation.

The effects of lack of insulin on the protein metabolism has not been studied in other organs. The nitrogen contents of the liver and kidneys were identical in control and diabetic free fed rats, indicating that hypoinsulinaemia does not alone determine the protein contents of these organs. The intestines of pair fed diabetic animals had the same nitrogen contents as that of the controls, whereas the nitrogen contents increased substantially in free fed rats. This indicates a lack of insulin effects, in accordance with the absence of insulin receptors in muscles of the intestines [20]. The heart and connective tissues, i.e. the skin, seem to be highly insulin dependent, as these organs lost protein irrespective of food intake.

One potentially important effect of the diabetic hyperglucagonaemia probably is to increase the capacity of urea synthesis (CUNS) [3]. In perfused rat livers glucagon increases the urea production from amino acids [21], and glucagon has been demonstrated to increase the activity of the urea cycle enzymes [22]. Treatment of normal rats with glucagon [23] increases CUNS. The increase in CUNS in both groups of diabetic animals reflects changes in the hepatic dynamics of amino nitrogen conversion, that are not merely the result of an increased load of substrates on the liver. It means that diabetic rats at any given amino acid concentration convert 2.5 -fold as much amino nitrogen into urea as do the controls. All three groups of animals showed identical fasting amino acid concentrations at the time of investigation, 4 weeks after induction of diabetes; and in accordance with this the pair fed diabetic animals excreted 2-2.5-fold more urea in the urine than did the controls.

This increase, however, was already seen 4-5 days after induction of diabetes where CUNS was not different from controls. CUNS first reaches the values seen in the present study 14 days after induction of diabetes [3]. Therefore changes in CUNS do not alone explain the present findings and cannot be the chronologically primary event in the nitrogen wasting of diabetes. Hyperglucagonaemia leads to increased transport of amino acids into the hepatocytes [24] and this may increase urea production by a substrate effect, independently of changes in urea enzyme activity as reflected by CUNS.

The free fed diabetic rats had an energy balance higher than that of the controls. It has been demonstrated that hyperglucagonaemia during hypoinsulin- 
aemia leads to an increased metabolic rate [25], and the increased energy balance might be a consequence of this.

Despite the better energy balance, the free fed diabetic rats were only partly able to compensate for the nitrogen loss of the pair fed diabetic rats and the nitrogen balances did not normalise. The incorporation of amino acids into protein is accelerated by insulin [26], and evidently the effect of lack of insulin could not be corrected by the increased food intake. Another possibility is that the changed kinetics of the hepatic amino nitrogen conversion, where increased amounts of amino acids are catabolised by the liver, deprives the tissues of amino acids for protein synthesis. Probably both mechanisms are operative.

In conclusion, the present study demonstrates that in uncontrolled diabetes most organs have reduced protein contents. More than one mechanism is operative. The skeletal muscles, the heart, and the connective tissues are most affected and respond least to increases in dietary nitrogen and energy. The liver and the kidneys have normal nitrogen contents in animals that increased their food intake, and the intestines even increased in nitrogen contents. The kinetics of the hepatic amino nitrogen conversion was changed so as to lead to increased conversion of amino acids into glucose and urea. This did not depend on the food intake. The diabetic tissue protein loss seems to depend on hypoinsulinaemia, food intake, and hepatic nitrogen elimination. The relative importance of each of these factors vary from organ system to organ system, and it is not known why proteins from different organs are affected differently.

Acknowledgements. The assistance of technicians B. Krog, L. L. Hansen, and K. Priisholm is gratefully acknowledged. Our thanks are due to technician A. Lieth, Department of Clinical Chemistry, Rigshospitalet, who kindly performed the analyses of the urine urea. The study was supported by grants from The Danish Foundations for the Advancement of Medical Science, The Danish Hospital Foundation for Medical Research (Region of Copenhagen, The Faeroe Islands and Greenland) and The P.Carl Petersen Foundation.

\section{References}

1. Atchley DW, Loeb RF, Richards DW, Benedict EM, Driscoll ME (1933) On diabetic acidosis. J Clin Invest 12:297 326

2. Wahren J, Felig P, Cerasi E, Luft R (1972) Splanchnic and peripheral glucose and amino acid metabolism in diabetes mellitus. J Clin Invest 51: 1870-1877

3. Almdal T, Petersen KF, Hansen BA, Vilstrup H (1986) Increased capacity of urea synthesis in experimental diabetes in rats. Diabetologia 29: 812-816

4. Fawcett JK, Scott JE (1960) A rapid and precise method for determination of urea. J Clin Pathol 13: 156-159

5. Goodwin JF (1970) Spectrophotometric quantitation of plasma and urinary amino nitrogen with flurodinitrobenzene. Stand Meth Clin Chem 6: 89-98

6. Ørskov H, Yde H, Thomsen HC (1968) Wick-chromatography for rapid and reliable immuno-assay of insulin, glucagon and growth hormone. Nature 219: 1993-1995
7. Heding LG (1971) Radioimmunological determination of pancreatic and gut glucagon in plasma. Diabetologia 7:10-17

8. Hansen BA, Vilstrup H (1985) A method for determination of the capacity of urea synthesis in the rat. Scand J Clin Lab Invest 45: 315-320

9. Duncan DB (1957) Multiple range test for correlated and heteroscedastic means. Biometrics 164-204

10. Rennie MJ (1985) Muscle protein turnover and the wasting due to injury and disease. Br Med Bull 41: 257-264

11. Pain VM, Garlick PJ (1974) Effects of streptozotocin diabetes and insulin treatment on the rate of protein synthesis in tissues of the rat in vivo. J Biol Chem 249: 4510-4514

12. Pain VM, Albertse EC, Garlick PJ (1983) Protein metabolism in skeletal muscle, diaphragm and heart of diabetic rats. Am J Physiol 245: E604-E610

13. Naakhooda AF, Wei C-N, Marliss EB (1980) Muscle protein catabolism in diabetes: 3-Methylhistidin excretion in the spontaneously diabetic "BB" rat. Metabolism 25: 1272-1277

14. Williams IH, Chua BML, Sahms RH, Siehl D, Morgan HE (1980) Effects of diabetes on protein turnover in cardiac muscle. Am J Physiol 239: E178-E185

15. McNurlan MA, Garlick PJ (1981) Protein synthesis in liver and small intestine in protein deprivation and diabetes. Am J Physiol 241: E238-E245

16. Jefferson LS, Liao WSL, Peavy DE, Miller TB, Appel MC, Taylor JM (1983) Diabetes-induced alterations in liver protein synthesis. J Biol Chem 258: 1369-1375

17. Jensen PK, Sandahl Christiansen J, Steven $\mathrm{K}$, Parving $\mathrm{H}-\mathrm{H}$ (1981) Renal function in streptozotocin-diabetic rats. Diabetologia 21: $409-414$

18. Jefferson LS, Li JB, Rannels SR (1977) Regulation by insulin of amino acid release and protein turnover in the perfused rat hemicorpus. J Biol Chem 252: 1476-1483

19. Fulks RM, Li BJ, Goldberg AL (1975) Effects of insulin, glucose, and amino acids on protein turnover in rat diaphragm. J Biol Chem 250: 290-298

20. Bergeron JJM, Rachubinski R, Searle N, Borts D, Sikstrom R, Posner BI (1980) Polypeptide hormone receptors in vivo. J Histochem Cytochem 28: 824-835

21. Mallette LE, Exton JH, Park CR (1969) Control of gluconeogenesis from amino acids in the perfused rat liver. J Biol Chem 244: 5713-5723

22. Snodgrass PJ, Lin RC, Muller WA, Aoki TT (1978) Induction of urea cycle enzymes of rat liver by glucagon. J Biol Chem 253: 2748-2753

23. Petersen KF, Hansen BA, Vilstrup H (1987) Time dependent stimulatory effect of glucagon on the capacity of urea- $\mathrm{N}$ synthesis in rats. Horm Met Res 19: 53-56

24. Fehlmann M, Le Cam A, Freychet $P$ (1979) Insulin and glucagon stimulation of amino acid transport in isolated rat hepatocytes. J Biol Chem 254: 10431-10437

25. Nair KS (1987) Hyperglucagonemia increases resting metabolic rate in man during insulin deficiency. $\mathbf{J}$ Clin Endocrinol Metab 64: 896-901

26. Manchester KL, Young FG (1958) The effect of insulin on incorporation of amino acids into protein of normal rat diaphragm in vitro. Biochem J 70: 353-358

Received: 15 July 1987

and in revised form: 12 October 1987

Dr. Thomas Almdal

Medical Department A-2151

Rigshospitalet

9 Blegdamsvej

DK-2100 Copenhagen

Denmark 